\title{
The effect of family ownership on the relation between executive compensation and performance: evidence from Thailand \\ J. Thomas Connelly ${ }^{a}$, Piman Limpaphayom ${ }^{b^{*}}$, Michael J. Sullivan ${ }^{c}$ \\ ${ }^{a}$ Faculty of Commerce and Accountancy, Chulalongkorn University \\ ${ }^{\mathrm{b}}$ Portland State University and Sasin GIBA of Chulalongkorn University \\ ${ }^{\mathrm{c}}$ Lee Business School, University of Nevada at Las Vegas \\ * Corresponding Author: Piman Limpaphayom, PhD, CFA, E-mail: piman@pdx.edu
}

\begin{abstract}
This study investigates the pay-performance relation for directors and managers in a sample of Thai public companies. It is hypothesized that family ownership mediates the pay-performance relations for directors and managers. The results show a strong link between managerial compensation and firm performance only for firms with low levels of family ownership. Conversely, there is a strong link between director compensation and firm performance only for firms with high levels of family ownership. The findings indicate that the relation between executive compensation and firm performance is more complex than previously documented.
\end{abstract}

Keywords: corporate governance, executive compensation, firm performance, family ownership

\section{Introduction}

Compensation contracts are utilized as a means of aligning the interests of agents (managers) with those of principals (owners) and can be designed to provide incentives aligning the behavior of managers to act on behalf of the shareholders. ${ }^{1}$ For large Western economies, studies typically find a positive relation between executive compensation and firm performance. $^{2}$ However, it may be problematic to rely on empirical studies based on the US experience to make policy inferences in other countries. Most nations have ownership structures which have dramatically higher levels of ownership concentration compared to US firms. ${ }^{3,4}$ In addition, shares of firms with concentrated ownership are frequently held by one or more families, where family shareholders often hold management positions.

In the case of these family firms, it is argued that the primary agency conflict is no longer between the managers and a wide base of outside shareholders. ${ }^{5}$ In fact, the primary agency conflict is between the controlling shareholder and minority or outside shareholders. Thus, a central question is whether compensation contracts are designed to mitigate this type of agency conflict. Previous studies on executive compensation have largely ignored the fact 
that compensation for managers and directors should therefore be examined simultaneously. Implicitly, these prior studies assume that managers and directors undertake the same decision-making roles. It is argued that the relation between pay and performance is much more complicated that previously assumed in the literature. Specifically, variations in ownership structure can lead to differences in agency conflicts. Furthermore, the roles of managers and directors may also vary according to the ownership structure.

\section{Literature review}

Ownership structure within a country is often a consequence of history and the resulting economic system and legal environment. ${ }^{6}$ For example, in emerging market economies, the presence of high ownership concentrations is shown to be a response to the lack of legal protection for shareholders. ${ }^{4}$ The founding family often holds a high ownership stake as a means of solving imperfections in corporate governance mechanisms and to provide an avenue for effective monitoring of managers. ${ }^{7}$ Therefore, it is common that most top executives of family controlled companies tend to come from the controlling family. ${ }^{3}$ Theory suggests that linking executive compensation to firm performance can mitigate agency problems by aligning managerial incentives with those of the owners. ${ }^{1}$ For Asian countries, previous studies demonstrate a positive relation between executive compensation and firm performance. ${ }^{8,9}$ However, other studies find no relation between executive pay and firm performance. ${ }^{10,11}$ These inconsistent results can be explained by the fact that previous studies did not account for the effect of family influences on the pay-performance relations. In the Philippines, for example, the relation between managerial pay and performance only exists for firms not affiliated with a family group. ${ }^{12}$

Like those in emerging markets in Asia, many listed companies in Thailand have a high concentration of family ownership. ${ }^{3}$ In addition, it is common for the top executives of family firms in Thailand to be family members themselves. ${ }^{13}$ As a result, many corporate governance mechanisms designed to monitor the top managers may be less important for family firms in Thailand. ${ }^{14}$ To attract outside investor, board independence and monitoring may also be viable solutions, especially in those cases where the founder is not actively running the firm. ${ }^{13}$

\section{Hypotheses}

It is hypothesized that ownership structure, particularly the presence of family ownership, determines which agency problem dominates and whether tying manager pay or board pay to 
performance best mitigates the dominant agency problem. Much like firms in the US, Thai firms with more diffuse ownership structures may be prone to owner-manager agency conflicts that may best be alleviated by tying managers pay to performance. In contrast, Thai firms with concentrated family ownership may be more likely prone to minority-majority owner agency conflicts that are best alleviated by tying board pay to performance. Significant minority owners, unrelated to the founding family, can have the latent ability to constrain the self-serving behavior of majority family shareholders. In addition, many family firms are willing to submit to some level of minority shareholder monitoring in order to attract outside funds and to build business alliances. Therefore, it is argued that one way to diminish the adverse effects of the manager-owner agency conflict, which is more likely to occur in a nonfamily firm with a diffuse base of owners, is to tie manager compensation to firm performance.

Hypothesis 1a. The relation between manager pay and performance is stronger for nonfamily firms than family firms.

In contrast, a way to diminish the majority owner-minority owner agency conflict, which may be more likely occur in a family firm, is to tie board compensation to performance.

Hypothesis $1 b$. The relation between board pay and performance is stronger for family firms than non-family firms.

\section{Data and methodology}

The sample consists of 218 non-financial firms listed on the Stock Exchange of Thailand (SET). Ownership information is gathered from the SETSMART database, which provides a list of the top ten shareholders for each firm. In addition, annual reports and annual regulatory filings (e.g. Form 56-1) are used to trace share ownership. Share ownership is categorized as family ownership for all family-controlled shares, including shareholders with the same surname and known familial relationships (relatives, spouses, children, etc.), even if the last names are different. Descriptive statistics for firm specific variables are presented in Table 1. Family ownership, defined as the number of shares owned by family members divided by the total number of shares outstanding, averages 36.5 percent across the sample indicating the high ownership concentration in Thailand. The dependent variables in the regression models are director compensation and manager compensation. Return on assets (ROA) is employed as the measure of firm performance. Corporate governance variables 
included in the analysis are the percentage of family ownership, CEO duality, CEO/founder dummy, Board Chair/founder dummy, board size, and board independence. Firm-specific variables include firm size, growth, leverage, and risk.

Table 1 - This table presents descriptive statistics for a sample of 218 public firms in Thailand.

\begin{tabular}{|l|r|r|r|r|c|}
\hline \multicolumn{1}{|c|}{ Variable } & \multicolumn{1}{c|}{ Mean } & \multicolumn{1}{c|}{ Median } & \multicolumn{1}{c|}{ Minimum } & Maximum & \multicolumn{1}{c|}{ SD } \\
\hline Family Ownership & 0.37 & 0.40 & 0.00 & 0.91 & 0.26 \\
\hline Board Size & 11.88 & 11.00 & 3.00 & 29.00 & 4.46 \\
\hline Board Independence & 0.34 & 0.33 & 0.14 & 0.73 & 0.11 \\
\hline Average Director Pay (mil. Baht) & 0.54 & 0.31 & 0.01 & 6.41 & 0.70 \\
\hline Average Manager Pay (mil. Baht) & 3.16 & 2.30 & 1.20 & 14.34 & 2.58 \\
\hline Return on Assets (ROA) & 0.06 & 0.05 & -0.19 & 0.32 & 0.08 \\
\hline Firm Size (Logarithm of Total Assets) & 15.11 & 14.97 & 11.90 & 20.29 & 1.42 \\
\hline Growth (3-year Asset Growth) & 0.48 & 0.29 & -0.72 & 4.48 & 0.77 \\
\hline Leverage (Debt/Total Assets) & 0.26 & 0.24 & 0.00 & 0.88 & 0.20 \\
\hline Risk (Standard Deviation of Returns) & 0.82 & 0.54 & 0.02 & 6.12 & 0.92 \\
\hline
\end{tabular}

\section{Empirical results}

Table 2 reports regression results with director compensation and management compensation as the dependent variables. The sample is classified into two groups based on the proportion of family ownership. The results of the models demonstrate that the pay-performance relation differs between high family-concentrated and low family-concentrated firms. Specifically, there is a positive relation between director pay and performance among high family ownership firms, whereas the positive relation between manager pay and performance holds only for low family ownership firms. In high family ownership firms, managers appear to be effectively monitored by family owners or are themselves members of the family. Therefore, it may not be beneficial to tie manager pay to firm performance. However, in these high family ownership firms, the monitoring role of the board may become correspondingly more important. This is consistent with our findings and the idea that conflicts between majority family owners and minority owners are more easily resolved at the board level. In low family ownership firms, managers are more likely to be outside professionals and may have greater decision-making responsibilities. As evidence, manager pay is found to be positively related to performance for low family ownership firms. These findings suggest that directors are the key decision-makers in family firms, whereas managers are the key decision-makers for the more widely-held, low family ownership firms. The empirical results provide support to the notion that in non-family firms, the overriding governance conflict is between the managers and a diffuse base of owners. The results also highlight to roles of board of directors for high family ownership firms. 
Table 2 - Regression Results between Executive Compensation and Firm Performance

\begin{tabular}{|c|c|c|c|c|}
\hline & \multicolumn{2}{|c|}{ Director Compensation } & \multicolumn{2}{|c|}{ Manager Compensation } \\
\hline & Low & High & Low & High \\
\hline \multirow[t]{2}{*}{ Return on Assets (ROA) } & 0.191 & 3.699* & $3.310^{*}$ & 0.082 \\
\hline & $(0.15)$ & $(3.29)$ & $(4.00)$ & $(0.12)$ \\
\hline \multirow[t]{2}{*}{ Family Ownership } & 0.059 & -0.442 & 0.557 & 0.047 \\
\hline & $(0.09)$ & $(-0.57)$ & $(1.35)$ & $(0.10)$ \\
\hline \multirow[t]{2}{*}{ CEO Duality } & 0.020 & -0.204 & -0.313 & 0.156 \\
\hline & $(0.06)$ & $(-0.75)$ & $(-1.50)$ & $(0.97)$ \\
\hline \multirow[t]{2}{*}{ Board Size } & -0.011 & 0.220 & -0.340 & 0.049 \\
\hline & $(-0.04)$ & $(0.92)$ & $(-1.90)$ & $(0.35)$ \\
\hline \multirow[t]{2}{*}{ Board Independence } & -0.337 & 0.077 & -0.173 & 0.226 \\
\hline & $(-1.03)$ & $(0.25)$ & $(-0.81)$ & $(1.23)$ \\
\hline \multirow[t]{2}{*}{ Firm Size } & $0.419 *$ & $0.548 *$ & $0.281^{*}$ & $0.426^{*}$ \\
\hline & $(5.82)$ & $(7.38)$ & $(6.03)$ & $(9.72)$ \\
\hline \multirow[t]{2}{*}{ Growth } & -0.032 & 0.250 & $-0.210 *$ & 0.105 \\
\hline & $(-0.28)$ & $(1.56)$ & $(-2.88)$ & $(1.11)$ \\
\hline \multirow[t]{2}{*}{ Leverage } & -0.163 & -0.882 & 0.246 & -0.436 \\
\hline & $(-0.31)$ & $(-1.80)$ & $(0.73)$ & $(-1.51)$ \\
\hline \multirow[t]{2}{*}{ Risk } & 0.008 & -0.054 & -0.030 & -0.033 \\
\hline & $(0.08)$ & $(-0.46)$ & $(-0.49)$ & $(-0.47)$ \\
\hline \multirow[t]{2}{*}{ Intercept } & 5.972* & 4.155* & 10.904* & $8.477 *$ \\
\hline & $(4.85)$ & $(3.41)$ & $(13.67)$ & $(11.75)$ \\
\hline Adj. R-squared & 0.251 & 0.456 & 0.447 & 0.482 \\
\hline F-statistics & $5.02 *$ & 11.04* & $10.72 *$ & $12.15 *$ \\
\hline $\mathrm{N}$ & 109 & 109 & 109 & 109 \\
\hline
\end{tabular}

\section{Conclusions}

The findings from this study highlight potential problems with generalizing empirical relations for director pay-performance or manager pay-performance. The results show that, under different ownership structures, the relations observed for director pay-performance are in sharp contrast to the relations uncovered for manager pay-performance. Given the relatively weak legal environment present in Thailand, it is not surprising to find evidence that the relation between pay and performance is affected by the firm's ownership structure. To date, nearly all previous pay-performance studies of firms in economies around the world have investigated only director pay or manager pay, but not both. In Thailand, the results also show that the pay-performance relations are mediate by the firms' ownership structure. These findings highlight the complex and dynamic nature of corporate governance in emerging markets. The interrelation between ownership structure and other corporate governance mechanisms are important considerations in the study of the roles of directors and managers. Finally, Asian regulators should emphasize the importance of disclosing the compensation of both managers and directors. 


\section{References}

1. M. Jensen, W. Meckling, Theory of the firm: Managerial behavior, agency costs and ownership structure. J. of Financial Economics 13 (1976) 305-360.

2. C. Devers, A. Cannella, G. Reilly, M. Yoder, Executive compensation: A multidisciplinary review of recent developments. J. of Management 33 (2007) 10161072.

3. S. Claessens, S. Djankov, L.H.P. Lang, The separation of ownership and control in East Asian corporations. J. of Financial Economics 58 (2000) 81-112.

4. R. La Porta, R. Lopez-de-Silanes, A. Shleifer, Corporate ownership around the world. J. of Finance 54 (1999) 471-517.

5. A. Shleifer, R. Vishny, A survey of corporate governance. J. of Finance 52 (1997) 737783.

6. R. La Porta, R. Lopez-de-Silanes, A. Shleifer, Law and Finance. J. of Political Economy 106 (1998) 1113-1155.

7. M. Burkhart, F. Panunzi, A. Shleifer, Family firms. J. of Finance 58 (2003) 2167-2201.

8. T. Kato, C. Long, Executive compensation, firm performance, and corporate governance in China: Evidence from firms listed in the Shanghai and Shenzhen stock exchanges. Economic Development and Cultural Change 54 (2005) 945-983.

9. T. Kato, W. Kim, J.H. Lee, Executive compensation, firm performance and chaebols in Korea: Evidence from new panel data. Pacific-Basin Finance J. 15 (2006) 36-55.

10. S. Cheng, M. Firth, Ownership, corporate governance and top management pay in Hong Kong. Corporate Governance: An International Review 13 (2005) 291-302.

11. K. Kubo, Executive compensation policy and company performance in Japan. Corporate Governance: An International Review 13 (2005) 429-436.

12. A. Unite, M.J. Sullivan, J., Brookman, M.A. Majadillas, A. Taningco, Executive pay and firm performance in the Philippines. Pacific-Basin Finance J. 16 (2008) 606-623.

13. M. Bertrand, S. Johnson, K. Samphantharak, A. Schoar, Mixing family with business: A study of Thai business groups and the families behind them. J. of Financial Economics 88 (2008) 466-498.

14. J.T. Connelly, P. Limpaphayom, N. Nagarajan, Form versus substance: The effect of ownership structure and corporate governance on firm value, J. of Banking and Finance 36 (2012) 1722-1743. 